Bull. Chem. Soc. Ethiop. 2020, 34(1), 135-140.

ISSN 1011-3924

(C) 2020 Chemical Society of Ethiopia and The Authors

Printed in Ethiopia

DOI: https://dx.doi.org/10.4314/bcse.v34i1.12

\title{
CHEMICAL CONSTITUENTS OF THE ROOT WOOD OF ERYTHRINA SACLEUXII AND DETERMINATION OF THE ABSOLUTE CONFIGURATION OF SUBERECTIN
}

\author{
Japheth O. Ombito $^{1 *}$, Gomotsang Bojase ${ }^{1}$, Runner R.T. Majinda ${ }^{1}$, Ishmael B. Masesane ${ }^{1}$, Anja \\ Schüffler ${ }^{2}$, Stefan Pusch $^{3}$, Carina Weber ${ }^{3}$ and Till Opatz ${ }^{3}$ \\ ${ }^{1}$ Department of Chemistry, University of Botswana, Private Bag 0022, Gaborone, Botswana \\ ${ }^{2}$ Institut für Biotechnologie und Wirkstoff-Forschung gGmbH, Erwin-Schrödinger-Straße 56, \\ D-67663 Kaiserslautern, Germany \\ ${ }^{3}$ Johannes Gutenberg University Mainz, Institute of Organic Chemistry, Duesbergweg 10-14, \\ D-55128 Mainz, Germany
}

(Received January 30, 2019; Revised January 29, 2020; Accepted January 30, 2020)

\begin{abstract}
Phytochemical investigation on the root wood of Erythrina sacleuxii (Leguminosae) led to the isolation of nine secondary metabolites (1-9). Compound $\mathbf{1}$ was isolated from the genus Erythrina for the first time. The pure compounds were identified on the basis of comprehensive spectroscopic and spectrometric analyses, while their absolute configurations were determined based on chiroptical measurements. Compounds 5 and $\mathbf{6}$ showed weak antifungal activity against Pyricularia oryzae with MIC values of $20 \mu \mathrm{g} / \mathrm{mL}$.
\end{abstract}

KEY WORDS: Erythrina sacleuxii, Leguminosae, Antifungal activity, Pyricularia oryzae

\section{INTRODUCTION}

The genus Erythrina, a member of Leguminosae family, is made up of more than 110 species of red or orange flowered trees or shrubs widely distributed in the tropical and subtropical regions of the world [1-3]. Erythrina sacleuxii Hua is a 9-24 m tall tree, endemic to Kenya and Tanzania [4]. Traditionally, the tree is used for the treatment of malaria fever and microbial infections [5, 6]. Previous phytochemical studies on the root and stem bark of the Kenyan specimens of $E$. sacleuxii had yielded flavones, isoflavones, isoflavanones, pterocarpans, and isoflav-3-enes [710], which have attracted interest on the account of their antiplasmodial activity [7]. We have recently reported some flavonoids from the stem bark and twigs of the Kenyan specimens of $E$. sacleuxii with antifungal and cytotoxic activities [11, 12]. As part of our continuing investigation on E. sacleuxii, herein, we report the isolation and structural elucidation of nine known compounds from the root wood of E. Sacleuxii (Figure 1) and their antifungal activity.

\section{EXPERIMENTAL}

General experimental procedures

Melting points were determined on a Stuart melting point apparatus SMP1 (UK) and are uncorrected. Silica gel $60 \AA(35-70 \mu \mathrm{m})$ from Acros Organics was used for column chromatography. Preparative TLC was performed on $20 \mathrm{~cm} \times 20 \mathrm{~cm}$ glass plates precoated with silica gel $60 \mathrm{PF}_{254+366}$ having $0.75 \mathrm{~mm}$ layer thickness. The spots and bands were visualized under a UV lamp (254 and $366 \mathrm{~nm}$ ). Optical rotation measurements were performed on a 241 model polarimeter (Perkin-Elmer, Waltham, MA, USA) at $22{ }^{\circ} \mathrm{C}$. NMR spectra were recorded on an Avance-III spectrometer (Bruker, Karlsruhe, Germany) at 400 and $100 \mathrm{MHz}\left({ }^{1} \mathrm{H}\right.$ and ${ }^{13} \mathrm{C}$,

*Corresponding author. E-mail: jeffombito@gmail.com

This work is licensed under the Creative Commons Attribution 4.0 International License 
respectively) equipped with a $5 \mathrm{~mm}$ probe head. The spectra were referenced to the residual solvent signal $[13,14]$. ESI-HRMS was obtained with a Q-ToF ULTIMA-III quadrupole TOF mass spectrometer (Waters, Eschborn, Germany). A Tensor 27 spectrometer (Bruker Optics, Ettlingen, Germany) equipped with a diamond ATR unit was used to record IR spectra. UV and ECD measurements were performed using a J-815 spectropolarimeter (Jasco, Tokyo, Japan) in a quartz glass cuvette with a path length of $1 \mathrm{~mm}$ and a spectral range of $400-185 \mathrm{~nm}$ at a scan speed of $20 \mathrm{~nm} / \mathrm{min}$ with 8 repetitions. The concentration of the acetonitrile solution of 1 amounted to $0.25 \mathrm{mmol} / \mathrm{L}$. The baseline was corrected by subtraction of a solvent spectrum obtained with the same parameters.

\section{Plant material}

The root wood of Erythrina sacleuxii was collected from Mutsengo, Kilifi County, along the Kenyan coast in August 2015. Identification and authentification of the plant species was performed by Prof. S.T. Kariuki of Biological Sciences, Egerton University. A voucher specimen of E. sacleuxii was deposited at the Department of Biological Sciences, Egerton University (no. 0136EUH).

\section{Extraction and isolation}

The root wood of E. sacleuxii (1.03 kg air-dried powder) was extracted with EtOAc (10 L) at room temperature for $72 \mathrm{~h}$ ( 3 times). The extract was concentrated under vacuum to afford a brown residue $(10 \mathrm{~g})$. The EtOAc extract was subjected to silica gel column chromatography using $n$-hexane with increasing proportions of EtOAc $(0-100 \%)$ to yield 11 fractions (A-K). Fraction D was chromatographed over silica gel eluting with $\mathrm{CHCl}_{3}-\mathrm{MeOH}$ (10:0.5) to afford two sub-fractions $\mathrm{D}_{1}$ and $\mathrm{D}_{2}$. Further purification of $\mathrm{D}_{1}$ by preparative TLC with $n$-hexaneEtOAc (4:1) yielded cristacarpin $(2,2.2 \mathrm{mg})$ and phaseollidin $(3,2.0 \mathrm{mg})$, while purification of $\mathrm{D}_{2}$ by silica gel column eluting with $\mathrm{CH}_{2} \mathrm{Cl}_{2}$-EtOAc (5:0.5) afforded $p$-hydroxybenzaldehyde (4, $5.4 \mathrm{mg}$ ). Fraction $\mathrm{E}$ was separated by silica gel column chromatography using $n$-hexane-acetone (5:1.5) and $\mathrm{CH}_{2} \mathrm{Cl}_{2}$-EtOAc (10:2.5) to give prostratol $\mathrm{C}(\mathbf{5}, 2.8 \mathrm{mg})$. Fraction $\mathrm{F}$ was purified by repeated silica gel column chromatography using $n$-hexane-acetone $(3: 2)$ to give orobol (6, $2.1 \mathrm{mg}$ ). Repeated column chromatographic purification of fraction $\mathrm{G}$ led to isolation of daidzein $(7,2.3 \mathrm{mg})$. Purification of fraction $\mathrm{H}$ by silica gel column chromatography using $\mathrm{CH}_{2} \mathrm{Cl}_{2}-\mathrm{MeOH}(5: 0.5)$ afforded 3'-methoxy coumestrol $(\mathbf{8}, 4.8 \mathrm{mg})$ and coumestrol $(\mathbf{9}, 1.3 \mathrm{mg})$. Fraction $\mathrm{K}$ was subjected to silica gel column chromatography eluting with $\mathrm{CHCl}_{3}-\mathrm{MeOH}(4: 1)$ to afford 2 sub-fractions $\mathrm{K}_{1}$ and $\mathrm{K}_{2}$. Further purification of $\mathrm{K}_{2}$ by preparative TLC using $\mathrm{CH}_{2} \mathrm{Cl}_{2}-\mathrm{MeOH}(5: 1.5)$ yielded suberectin $(1,13 \mathrm{mg})$.

Suberectin (1)

Brown powder; $\mathrm{mp}\left(168-170{ }^{\circ} \mathrm{C}\right) ;[\alpha]_{\mathrm{D}}^{22}-4.0^{\circ}(\mathrm{c} 0.1, \mathrm{MeCN})$; IR (ATR): $3352,1655,1616,1504$, $1471,1279,1152 \mathrm{~cm}^{-1}$; UV/Vis $\lambda_{\max }(\mathrm{MeCN}) \mathrm{nm}(\log \varepsilon): 200$ (4.70), 235 (4.32), 272 (4.11), 330 (3.76); ${ }^{1} \mathrm{H}$ NMR, COSY (400 MHz, acetone- $\left.d_{6}\right): 5.33(1 \mathrm{H}, d d, J=13.0,3.0 \mathrm{~Hz}, \mathrm{H}-2), 2.99(1 \mathrm{H}$, $d d, J=16.8,13.0 \mathrm{~Hz}, \mathrm{H}-3 \mathrm{a}), 2.67(1 \mathrm{H}, d d, J=16.8,3.0 \mathrm{~Hz}, \mathrm{H}-3 \mathrm{~b}), 7.24(1 \mathrm{H}, s, \mathrm{H}-5), 3.81(3 \mathrm{H}$, $\left.s, 6-\mathrm{OCH}_{3}\right), 6.45(1 \mathrm{H}, s, \mathrm{H}-8), 7.05(1 \mathrm{H}, \mathrm{d}, J=2.1 \mathrm{~Hz}, \mathrm{H}-2), 6.86\left(2 \mathrm{H}, d, m, \mathrm{H}-5^{\prime}\right.$ and $\left.\mathrm{H}-6{ }^{\prime}\right) ;{ }^{13} \mathrm{C}$ NMR (100 MHz, acetone- $\left.d_{6}\right)$ : 79.6 (C-2), 43.5 (C-3), 190.2 (C-4), 106.9 (C-5), 143.3 (C-6), 154.5 (C-7), 103.4 (C-8), 158.1 (C-9), 112.7 (C-10), 131.0 (C-1'), 113.7 (C-2'), 144.9 (C-3'), $146.2\left(\mathrm{C}^{-} 4^{\prime}\right), 115.1\left(\mathrm{C}-5^{\prime}\right), 118.2\left(\mathrm{C}^{-} 6^{\prime}\right), 55.5\left(6-\mathrm{OCH}_{3}\right)$; ESI-HRMS: $m / z\left[\mathrm{M}+\mathrm{H}^{+}\right]$calcd. for $\mathrm{C}_{16} \mathrm{H}_{14} \mathrm{O}_{6}: 303.0863$; found: 303.0863 . 


\section{RESULTS AND DISCUSSION}

Phytochemical investigation on the root wood of E. sacleuxii led to the isolation and identification of nine known compounds. The known compounds were identified as suberectin (1) [15], cristacarpin (2) [16], phaseollidin (3) [17], p-hydroxybenzaldehyde (4) [18], prostratol C (5) [19], orobol (6) [20], daidzein (7) [21], 3'-methoxy coumestrol (8) [22] and coumestrol (9) [23]. Their chemical structures were established by comparison of their spectroscopic and spectrometric data with the literature data. Whereas compounds (2-9) have been reported from the genus Erythrina before, this is the first report of the existence of suberectin (1) in the genus Erythrina.

Compound 1 was isolated as a brown powder and assigned the molecular formula $\mathrm{C}_{16} \mathrm{H}_{14} \mathrm{O}_{6}$ determined on the basis of ESI-HRMS data $\left([\mathrm{M}+\mathrm{H}]^{+} m / z\right.$ 303.0863, calcd. 303.0863) and NMR analyses. The ${ }^{1} \mathrm{H}$ NMR spectrum of compound 1 displayed signals characteristic for a flavanone skeleton with an oxymethine proton resonance at $\delta_{\mathrm{H}} 5.33(13.0,3.0 \mathrm{~Hz}, \mathrm{H}-2)$ coupled to methylene protons resonance at $\delta_{\mathrm{H}} 2.99(16.8,13.0 \mathrm{~Hz}, \mathrm{H}-3 \mathrm{ax})$ and $\delta_{\mathrm{H}} 2.67(16.8,3.0 \mathrm{~Hz}, \mathrm{H}-2 \mathrm{eq})$ indicating the presence of axial and equatorial protons in ring $\mathrm{C}$ of the flavonoid [24]. Two para-oriented aromatic proton singlets at $\delta_{\mathrm{H}} 7.24$ and $\delta_{\mathrm{H}} 6.45$ were assigned to $\mathrm{H}-5$ and $\mathrm{H}-8$, respectively, based on the HMBC cross-peaks of H-5 with C-4 $\left(\delta_{\mathrm{C}} 190.2\right)$, C-6 $\left(\delta_{\mathrm{C}} 143.3\right), \mathrm{C}-7$ $\left(\delta_{\mathrm{C}} 154.5\right), \mathrm{C}-8\left(\delta_{\mathrm{C}} 103.4\right), \mathrm{C}-9\left(\delta_{\mathrm{C}} 158.1\right), \mathrm{C}-10\left(\delta_{\mathrm{C}} 112.7\right)$ and $\mathrm{H}-8$ with C-4 $\left(\delta_{\mathrm{C}} 190.2\right), \mathrm{C}-5\left(\delta_{\mathrm{C}}\right.$ $106.9), \mathrm{C}-7\left(\delta_{\mathrm{C}} 154.5\right), \mathrm{C}-9\left(\delta_{\mathrm{C}} 158.1\right)$, and $\mathrm{C}-10\left(\delta_{\mathrm{C}} 112.7\right)$. The methoxyl group $\left(\delta_{\mathrm{H}} 3.81, \delta_{\mathrm{C}}\right.$ $55.5)$ was placed at C-6 based on its HMBC correlation to C-6 $\left(\delta_{\mathrm{C}} 143.23\right)$. The signals of aromatic protons of ring B comprised a doublet at $\delta_{\mathrm{H}} 7.05\left(1 \mathrm{H}, 2.1 \mathrm{~Hz}, \mathrm{H}-2^{\prime}\right)$ and a multiplet at $\delta_{\mathrm{H}} 6.86\left(2 \mathrm{H}, m, \mathrm{H}-5^{\prime} / 6^{\prime}\right)$. The lack of splitting between $\mathrm{H}-5^{\prime}$ and $6^{\prime}$ could be due to dynamic process as a result of tautomerism between flavanone and chalcone. Furthermore, the small specific rotation value as a result of partial racemization due to inter-conversion between flavanone and chalcone suggests a free $-\mathrm{OH}$ at $\mathrm{C}-4^{\prime}$.

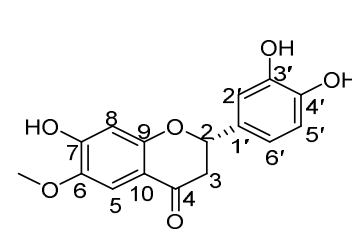

1
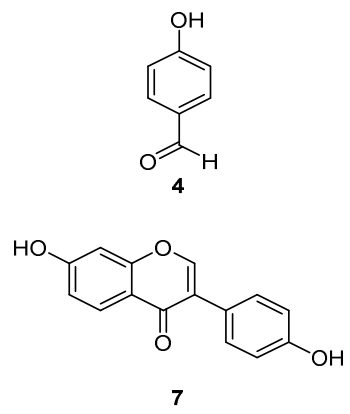

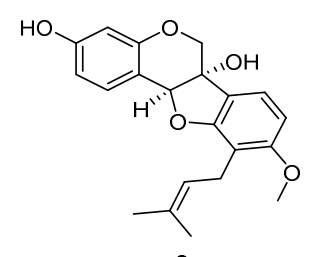

2
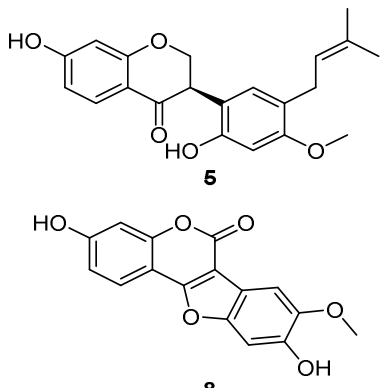

8

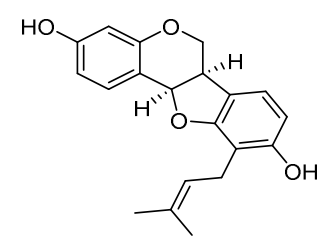

3

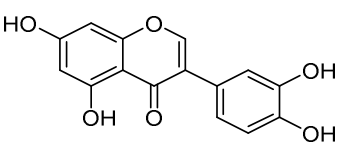

6

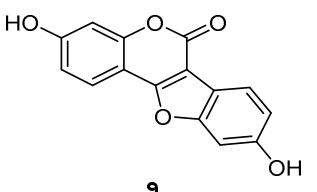

Figure 1. Structures of compounds 1-9.

The absolute configuration of (-)-suberectin which is reported for the first time was determined by comparing the experimental ECD spectrum with a TDDFT calculated ECD 
spectrum of (-)-suberectin (Figure 2). The experimental ECD spectrum of (-)-suberectin exhibited a positive Cotton effect at around $\lambda=340 \mathrm{~nm}$ as well as a negative Cotton effect at around $310 \mathrm{~nm}$ (Figure 2). Such observations in an ECD spectrum according to Gaffield, suggest that the compound should have an absolute configuration of $(2 S)$ [25].

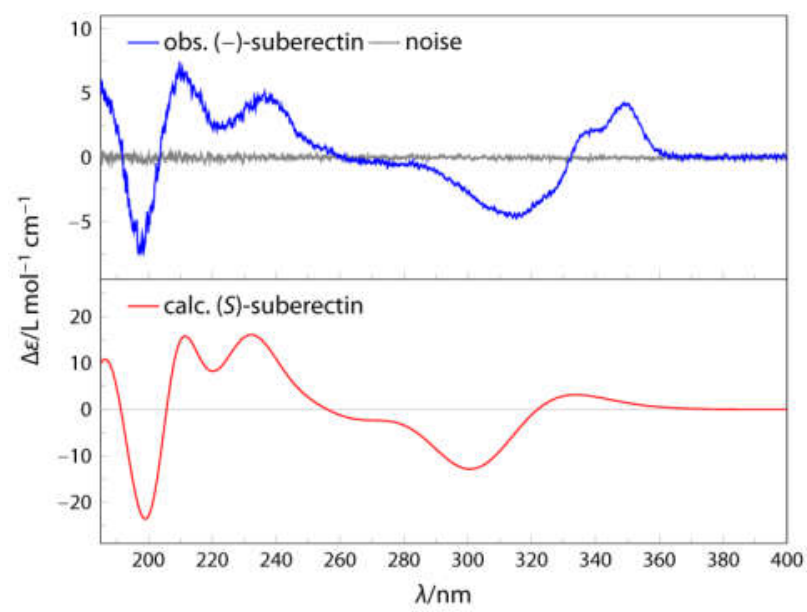

Figure 2. Observed ECD spectrum of (-)-suberectin in acetonitrile (top, blue) and calculated ECD spectrum of $(\mathrm{S})$-suberectin (bottom, red).

To further confirm the absolute configuration of (-)-suberectin as (2S), its UV and ECD spectra were calculated using TDDFT at the TD- $\omega$ B97XD/6-311G++(d,p)/IEFPCM//B3LYP/6$311 \mathrm{G}(\mathrm{d}, \mathrm{p}) / \mathrm{IEFPCM}$ level of theory. Comparison of the observed and theoretical spectra was performed using the procedure established by Bringmann and co-workers [26-28]. The calculated ECD spectrum of $(S)$-suberectin showed a similarity of $85.2 \%$ to the experimental one, whereas the calculated ECD spectrum of $(R)$-suberectin yielded only $1.23 \%$ similarity. The difference value (also called enantiomeric similarity index, ESI) therefore amounts to $83.97 \%$. This observation further confirmed that (-)-suberectin has an absolute configuration of $(2 S)$. It is worth noting that (-)-suberectin can adopt four relevant conformations which only differ in the orientation of the hydroxyl groups of the phenyl substituent. The two most important conformers yield very similar ECD spectra (Figure 3). For the lowest energy conformer, natural transition orbitals were calculated. The positive Cotton effect at approx. $\lambda=340 \mathrm{~nm}$ seems to be caused by $n \rightarrow \pi^{*}$ transition in the chromanone unit, whereas the negative Cotton effect at $310 \mathrm{~nm}$ is due to $\pi \rightarrow \pi^{*}$ transition. At around $260 \mathrm{~nm}$ (scaled wavelength), two ECD bands appear to cancel each other. The positive Cotton effect at around $240 \mathrm{~nm}$ is predicted to originate from another chromanone $\pi \rightarrow \pi^{*}$ transition.

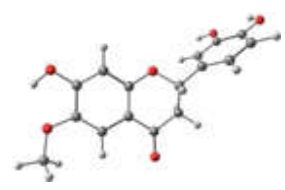

I

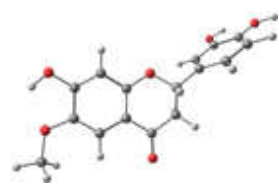

II

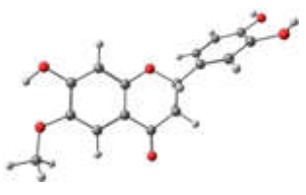

III

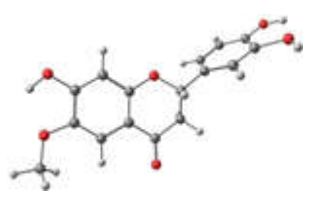

IV

Figure 3. Conformations of $(S)$-suberectin. 
Biological activity

The in vitro antifungal activity of the isolated compounds were tested against a panel of pathogens, including Botrytis cinerea, Candida albicans, Eremothecium coryli, Penicillium notatum, Pyricularia oryzae, and Rhizomucor miehei as agar diffusion assays as per the method described previously [29] with minor modifications. Compounds 5 and $\mathbf{6}$ showed weak activity against $P$. oryzae with MIC values of $20 \mu \mathrm{g} / \mathrm{mL}$. The rest of the compounds did not show any appreciable activity. The positive control, ciclopirox, had an MIC of $5 \mu \mathrm{g} / \mathrm{mL}$.

\section{ACKNOWLEDGMENTS}

J.O.O. thanks German Academic Exchange Service (DAAD) for a Ph.D. fellowship, offered through the Natural Products Research Network for Eastern and Central Africa (NAPRECA). The authors are grateful to Prof. S.T. Kariuki of Biological Sciences, Egerton University, for plant identification. We thank Dr. J. C. Liermann and Dr. C. Kampf (both from University of Mainz) for NMR spectroscopy and mass spectrometry. Prof. Pol Besenius is kindly acknowledged for granting access to his ECD spectrometer. We thank the Zentrumfür Datenverarbeitung (Univ. Mainz) for access to the MOGON supercomputer and the Impulsfonds der Forschungsinitiative Rheinland-Pfalz for support under the programme LESSING. This work was supported by the Naturstoffzentrum Rheinland-Pfalz.

\section{REFERENCES}

1. Fahmy, N.M.; Al-Sayed, E.; El-Shazly, M.; Nasser Singab, A. Alkaloids of genus Erythrina: An updated review. Nat. Prod. Res. 2019, 1-22. DOI: 10.1080/14786419.2018.1564300.

2. Fahmy, N.M.; Al-Sayed, E.; El-Shazly, M.; Singab, A.N. Comprehensive review on flavonoids biological activities of Erythrina plant species. Ind. Crops Prod. 2018, 123, 500538.

3. Majinda, R.R.T. An update of erythrinan alkaloids and their pharmacological activities, in Progress in the Chemistry of Organic Natural Products 107, 2018, Springer: p 95-159.

4. Kone, W.M.; Solange, K.; Dosso, M. Assessing sub-Saharan Erythrina for efficacy: Traditional uses, biological activities and phytochemistry. Pak. J. Biol. Sci. 2011, 14, 560571.

5. Kokwaro, J.O. Medicinal Plants of East Africa, Kenya Literature Bureau: Nairobi, Kenya; 1993; p 158.

6. Gessler, M.C.; Nkunya, M.H.H.; Mwasumbi, L.B.; Heinrich, M.; Tanner, M. Screening Tanzanian medicinal plants for antimalarial activity. Acta Trop. 1994, 56, 65-77.

7. Andayi, A.W.; Yenesew, A.; Derese, S.; Midiwo, J.O.; Gitu, P.M.; Jondiko, O.J.I.; Akala, H.; Liyala, P.; Wangui, J.; Waters, N.C. Antiplasmodial flavonoids from Erythrina sacleuxii. Planta Med. 2006, 72,187-189.

8. Yenesew, A.; Midiwo, J.O.; Heydenreich, M.; Peter, M.G. Four isoflavones from the stem bark of Erythrina sacleuxii. Phytochemistry 1998b, 49, 247-249.

9. Yenesew, A.; Midiwo, J.O.; Heydenreich, M.; Schanzenbach, D.; Peter, M.G. Two isoflavanones from the stem bark of Erythrina sacleuxii. Phytochemistry 2000, 55, 457-459.

10. Yenesew, A.; Midiwo, J.O.; Miessner, M.; Heydenreich, M.; Peter, M.G. Two prenylated flavanones from stem bark of Erythrina burttii. Phytochemistry 1998, 48, 1439-1443.

11. Ombito, J.O.; Bojase, G.; Majinda, R.R.T.; Masesane, I.B.; Schüffler, A.; Opatz, T. Erysacleuxins C and D, new isoflavones from the twigs of Erythrina sacleuxii Hua and their cytotoxic activity. Arabian J. Chem. 2019, in press. 
12. Ombito, J.O.; Majinda, R.R.T.; Masesane, I.B.; Bojase, G.; Schüffler, A.; Opatz, T. Prenylated isoflavones from the stem bark of Erythrina sacleuxii. Phytochem. Lett. 2018, 26, 110-114.

13. Gottlieb, H.E.; Kotlyar, V.; Nudelman, A. NMR chemical shifts of common laboratory solvents as trace impurities. J. Org. Chem. 1997, 62, 7512-7515.

14. Fulmer, G.R.; Miller, A.J.M.; Sherden, N.H.; Gottlieb, H.E.; Nudelman, A.; Stoltz, B.M.; Bercaw, J.E.; Goldberg, K.I. NMR chemical shifts of trace impurities: Common laboratory solvents, organics, and gases in deuterated solvents relevant to the organometallic Chemist. Organometallics 2010, 29, 2176-2179.

15. Cui, Y.; Liu, P.; Chen, R. Studies on the chemical constituents of Spatholobus suberectus Dunn. Yao Xue Xue Bao 2002, 37,784-787.

16. Dagne, E.; Gunatilaka, A.A.L.; Kingston, D.G.I.; Alemu, M.; Hofmann, G.; Johnson, R.K. Two bioactive pterocarpans from Erythrina burana. J. Nat. Prod. 1993, 56, 1831-1834.

17. Shirataki, Y.; Noguchi, M.; Yokoe, I.; Tomimori, T.; Komatsu, M. Sophoraflavanones H, I and J, flavonostilbenes from Sophora moorcroftiana. Chem. Pharm. Bull. 1991, 39,15681572 .

18. Denton, S.; Dunnett, N.; Walls, H.J. para-Hydroxybenzaldehyde in human viscera. Nature 1963, 198, 793-794.

19. Iinuma, M.; Ohyama, M.; Tanaka, T. Three isoflavanones from roots of Sophora prostrata. Phytochemistry 1994, 37, 1713-1716.

20. Nishiola, H.; Imoto, M.; Sawa, T.; Hamada, M.; Naganawa, H.; Takeuchi, T.; Umezawa, K. Screening of phosphatidyl-inositol kinase inhibitors from Streptomyces. J. Antibiot. 1989, 42, 823-825.

21. Nkengfack, A.E.; Waffo, A.K.; Azebaze, G.A.; Fomum, Z.T.; Meyer, M.; Bodo, B.; van Heerden, F.R. Indicanine A, a new 3-phenylcoumarin from root bark of Erythrina indica. $J$. Nat. Prod. 2000, 63, 855-856.

22. Bickoff, E.M.; Spencer, R.R.; Knuckles, B.E.; Lundin, R.E. 3'-Methoxycoumestrol from Alfalfa: Isolation and characterization. J. Agric. Food Chem. 1966, 14, 444-446.

23. Bickoff, E.M.; Booth, A.N.; Lyman, R.L.; Livingston, A.L.; Thompson, C.R.; Kohler, G.O. Isolation of a new estrogen from ladino clover. J. Agric. Food Chem. 1958, 6, 536-539.

24. Nkengfack, A.E.; Sanson, D.R.; Tempesta, M.S.; Fomum, Z.T. Two new flavonoids from Erythrina eriotriocha. J. Nat. Prod. 1989, 52, 320-324.

25. Gaffield, W. Circular dichroism, optical rotatory dispersion and absolute configuration of flavanones, 3-hydroxyflavanones and their glycosides: Determination of aglycone chirality in flavanone glycosides. Tetrahedron 1970, 26, 4093-4108.

26. Bruhn, T.; Schaumlöffel, A.; Hemberger, Y.; Bringmann, G. SpecDis: Quantifying the comparison of calculated and experimental electronic circular dichroism spectra. Chirality 2013, 25, 243-249.

27. Pescitelli, G.; Bruhn, T. Good computational practice in the assignment of absolute configurations by TDDFT calculations of ECD spectra. Chirality 2016, 28, 466-474.

28. Bruhn, T.; Schaumlöffel, A.; Hemberger, Y.; Pescitelli, G. SpecDis, Version 1.71. Berlin, Germany; 2017.

29. Anke, H.; Bergendorff, O.; Sterner, O. Assays of the biological activities of guaiane sesquiterpenoids isolated from the fruit bodies of edible Lactarius species. Food Chem. Toxicol. 1989, 27, 393-397. 